\title{
PEMBERDAYAAN PEREMPUAN DALAM PENGENTASAN KEMISKINAN BERBASIS PROGRAM PEMBERDAYAAN DAN KESEJAHTERAAN KELUARGA (PKK)
}

\author{
Muhammad Rapii ${ }^{1)}$, Wahdatussopia ${ }^{2)}$ \\ Universitas Hamzanwadi NTB ${ }^{1}$ \\ Email: mrapii166@gmail.com ${ }^{1}$
}

\begin{abstract}
ABSTRAK
Penelitian ini dimaksudkan untuk mendapatkan gambaran pelaksanaan Program Pemberdayaan dan Kesejahteraan Keluarga (PKK) di wilayah Kecamatan Aikmel khususnya dalam bidang usaha mandiri; serta pemanfaatan bantuan program pemberdayaan dan kesejahteraan keluarga terhadap pengembangan usaha. Penelitian ini merupakan penelitian deskriptif dengan pengambilan sampel secara simple random. Pengumpulan data menggunakan wawancara, obeservasi dan dokumentasi. Analisis data yang digunakan adalah analisis deskriptif kualitatif. Hasilnya menunjukkan bahwa, yaitu indikator keberhasilan pelatihan diantaranya adalah Partisipasi, sikap kerjasama, pengetahuan, keterampilan, mengembangkan pengetahauna, inovasi, informasi, usaha diri dan tingkat penghasilan yang meningkat.
\end{abstract}

Kata kunci: Pemberdayaan Perempuan, Program, Kesejahteraan Keluarga

\begin{abstract}
I intend this research to get an overview of implementing the Family Empowerment and Welfare Program (FEW) in the Aikmel District area, especially in independent business; and the utilization of family empowerment and welfare program help for business development. This research is a descriptive study with simple random sampling. Data collection uses interviews, observation and documentation. Analysis of the data used is descriptive qualitative analysis. The results show that the indicators of training success include participation, cooperative attitude, knowledge, skills, developing knowledge, innovation, information, self-effort and increased income levels.
\end{abstract}

Keywords: women's empowerment, Programs, family empowerment 


\section{PENDAHULUAN}

Pemerintah Indonesia berkomitmen mencapai target dari program Sustainable Development Goals (SDG's) pada tahun 2030. Salah satu target utamanya terkait dengan pembangunan anak Indonesia. Target yang ingin dicapai diantaranya adalah penghapusan kemiskinan anak; tidak ada lagi anak-anak kekurangan gizi dan meninggal karena penyakit yang bisa diobati; menciptakan lingkungan yang ramah terhadap anak; memenuhi kebutuhan pendidikan anak khususnya pendidikan di usia dini; dan target lainnya. Bermacam strategi untuk mencapai target tersebut telah disusun dengan baik serta berkesinambungan agar dapat diimplementasikan dengan tepat demi kesejahteraan anak-anak Indonesia.

Pada periode 2019-2024, Kemen PPPA memiliki lima isu prioritas pembangunan pemberdayaan perempuan dan perlindungan anak. Kelima isu prioritas tersebut, yaitu: (1) peningkatan pemberdayaan perempuan dalam kewirausahaan; (2) peningkatan peran orang tua dalam pendidikan anak; (3) penurunan kekerasan terhadap perempuan dan anak; (4) penurunan pekerja anak; dan (5) pencegahan perkawinan anak.

Keberhasilan pembangunan kualitas hidup manusia yang diukur melalui IPM masih belum cukup efektif memperkecil kesenjangan antara laki-laki dan perempuan baik di level nasional, provinsi maupun kabupaten dan kota. Oleh sebab itu, pemerintah baik di pusat dan daerah harus mampu menyusun program pembangunan yang lebih responsif gender, sehingga kesetaraan gender bisa terwujud paling lama di tahun 2025 mendatang sebagaimana target pemerintah. Hal tersebut ditujukan agar perempuan juga mampu secara optimal menikmati perannya sebagai subyek sekaligus objek pembangunan.

Keterlibatan pemerintah dalam menyikapi fenomena kemiskinan sangatlah strategis dengan menempuh kebijakan yang dapat melahirkan program/kegiatan pembangunan secara terpadu antara pertumbuhan dan pemerataan, termasuk di dalamya upaya peningkatan peran pemerintah yang lebih mampu menggerakkan peran serta masyarakat dalam pembangunan dan merubah pola pikir serta sikap mental mereka. Melalui upaya terpadu ini, diharapkan dapat mengikutsertakan masyarakat dalam kelompok kehidupannya serta membantu dan memberdayakan mereka dalam berbagai kegiatan produktif yang sesuai dengan potensinya masing-masing.

Program penanggulangan kemiskinan semakin banyak jumlahnya seiring dengan kian meluasnya krisis ekonomi. Program yang ditawarkan pada tahap ini antara lain adalah Pemberdayaan Daerah dalam mengatasi Dampak Krisis Ekonomi (PDM-DKE), Kumanis (Kredit Usaha Masyarakat Terkena Krisis), Pemberdayaan Ekonomi Masyarakat (PEM), bantuan Alsintan (Alat Mesin Pertanian), Pemberdayaan Ekonomi Masyarakat Pesisir (PEMP), serta penyertaan modal bagi koperasi dan lembaga keuangan Masyarakat (LKM). Namun fokus perhatian terhadap kebijakan tersebut, tidak lebih hanyalah merupakan kegiatan formal administrasi pemerintahan sehingga unsur-unsur penting dalam pelaksanaan program terabaikan. Seperti halnya kebijakan Inpres Bantuan Desa, yang cenderung menekankan pada tertib administrasi pertanggungjawaban atau SPJ saja, atau terkadang juga sering terdengar bahwa program-program pemberdayaan yang dilakukan sering bernuansa proyek. Jika proyeknya selesai, maka selesai pula kegiatan pemberdayaannya. Akibat dari program- 
program seperti ini adalah tidak tersentuhnya maksud utama dari pemberdayaan masyarakat itu sendiri, yaitu terwujudnya masyarakat miskin yang tidak berdaya menjadi berdaya atau dengan kata lain masyarakat sasaran pemberdayaan benar-benar menjadi mandiri (BNP2TKI, 2019).

Perkembangan pemberdayaan perempuan di Indonesia atas dasar pemberdayaan berbasis gender di dukung oleh Pemerintah melalui Kementerian Negara Pemberdayaan Perempuan dan Perlindungan Anak (KPPPA) telah mengupayakan berbagai hal dalam meningkatkan peran perempuan dalam kapabilitasnya. Hasil dari peningkatan pemberdayaan perempuan di Indonesia terlihat dalam tabel Indeks Pemberdayaan Gender (IDG) pada tahun 2010-2014 menunjukkan peningkatan. Tahun 2010 IDG menunjukkan angka 68,15 persen, naik menjadi 69,14 persen pada tahun 2011. Pada tahun 2012 mengalami peningkatan menjadi 70,07 persen. Tahun 2013 naik menjadi 70,46 persen dan pada tahun 2014 mengalami peningkatan menjadi 70,68 persen. Peningkatan IDG dari 2010-2014 menunjukan bahwa peran perempuan dalam pengambilan keputusan dalam kegiatan ekonomi semakin baik dan potensial (KPPPA, 2019).

Manusia sebagai insan dan sumberdaya pembangunan merupakan satu kesatuan yang tidak terpisahkan. Kemampuan bangsa untuk berdaya saing tinggi akan menjadikan Indonesia siap menghadapi tantangan globalisasi dan mampu memanfaatkan peluang yang ada. Untuk memperkuat daya saing bangsa, pembangunan nasional diarahkan untuk mengedepankan pembangunan kualitas hidup manusia. Artinya, faktor pembangunan kualitas hidup manusia menjadi pokok perhatian di semua bidang pembangunan. Pembangunan kualitas hidup manusia merupakan upaya terusmenerus yang dilakukan pemerintah dalam rangka mencapai kehidupan yang lebih baik.

Pemberdayaan adalah kemampuan untuk mengelola atau memanag sebuah nilai yang ada pada diri sumberdaya manusia baik secara kelompok maupun secara individu yang bertujuan agar mampu berdikari sesuai dengan keinginan. Sedangkan pemberdayaan perempuan dalam lingkup mikro merupakan langkah-langkah yang diambil untuk memperoleh nilai tambah yang berguna bagi diri manusia. Perkembangan peradaban di Indonesia saat ini tumbuh dalam lingkup budaya dan ideologi praktis sehingga meninggalkan dampak negatif diberbagai aspek kehidupan dan struktur masyarakat serta telah menciptakan ketimpangan gender (Sukidjo, Teguh Sihono, 2014).

Mengutip definisi yang dikemukakan oleh UNDP, Empowerment (pemberdayaan) dianggap sebagai sebuah proses yang memungkinkan kalangan individual ataupun kelompok merubah keseimbangan kekuasaan dalam segi sosial, ekonomi maupun politik pada sebuah masyarakat ataupun komunitas. Kegiatan pemberdayaan dapat mengacu pada banyak kegiatan, di antaranya adalah meningkatkan kesadaran akan adanya kekuatan-kekuatan sosial yang menekan orang lain dan juga pada aksi-aksi untuk mengubah pola kekuasaan di masyarakat. Sedangkan secara etimologis pemberdayaan berasal dari kata dasar "daya" yang berarti kekuatan atau kemampuan (Diwanti et al., 2019).

Pemberdayaan perempuan adalah upaya memper baiki status dan peran perempuan dalam pembangunan bangsa, sama halnya dengan kualitas peran dan 
kemandirian organisasi perempuan. Daulay menyampaikan bahwa program pemberdayaan perempuan di Indonesia pada hakekatnya telah dimulai sejak tahun 1978. Dalam perkembangannya upaya dalam kerangka pemberdayaan perempuan ini secara kasat mata telah menghasilkan suatu proses peningkatan dalam berbagai hal. Seperti peningkatan dalam kondisi, derajat, dan kualitas hidup kaum perempuan di berbagai sektor strategis seperti bidang pendidikan, ketenagakerjaan, ekonomi, kesehatan dan keikutsertaan ber-KB (Kuncoro \& Kadar, 2016).

Kemudian dari jenisnya, pemberdayaan/penguatan dapat dilihat pada dua level, individual dan komunitas. Pada tataran individual, isu-isu yang relevan dengan pemberdayaan adalah: hubungan patron-klien, gender, akses ke pemerintahan (negara), dan sumbersumber kepemilikan properti. Sementara pada tataran komunitas, isu-isu utama yang biasa diangkat adalah: mobilisasi sumberdaya (resources mobilization), pemberdayaan/penguatan kerangka institusional dan akses hubungan (linkages) dengan badan-badan pemerintah.

Selain itu secara teori terdapat beberapa diantaranya pengertian umum studi perempuan yaitu segala sesuatu yang fokus pembahasannya tentang perempuan, baik tentang sejarah dari perempuan, tentang faktor-faktor yang mempengaruhi posisi perempuan di masyarakat yang berbeda-beda, tentang peran perempuan dalam pembangunan (Saptatiningsih, 2015). Permasalahan perempuam di bidang ekonomi tidak terlepas dari masalah kemiskinan. Tiga pendekatan kemiskinan yaitu: pertama, kemiskinan kultural yang mana kemiskinan masih dipengaruhi oleh budaya tradisional dengan terbatasnya perempuan dalam mendapatkan akses dalam memperoleh penghasilan. Kedua, kemiskinan struktural, adanya kemiskinan struktural ini diakibatkan oleh kemiskinan kultural karena rendahnya pendidikan dan rendahnya ketrampilan perempuan sebagian besar perempuan yang berada diwilayah pedesaan. Ketiga, kemiskinan alamiah menjelaskan bahwa sebagian perempuan yang bersikap pasrah terhadap posisi dirinya dalam kehidupan rumah tangga dan masyarakat. Pemberdayaan (Empowerment) merupakan proses perubahan pribadi karena masingmasing individu mengambil tindakan atas nama diri mereka sendiri dan kemudian mempertegas pemahamannya terhadap dunia. Pemberdayaan merupakan suatu proses yang menyangkut hubungan kekuatan (kekuasaan) yang berubah antara individu, kelompok dan lembaga sosial lainnya (Shrangge, 1993 dalam buku Women in Public Sector) (Goyena \& Fallis, 2019).

\section{METODE PENELITIAN}

Penelitian ini merupakan penelitian deskriptif, dilakukan untuk mendapatkan gambaran pelaksanaan program pemberdayaan dan kesejahteraan keluarga (PKK) di Kecamatan Aikmel. Penentuan sampel dilakukan secara bertahap, untuk menentukan sampel kecamatan dipilih yang memiliki desa tertinggal. Selanjutnya untuk menentukan desa dan responden dilakukan dengan simple random, diperoleh 90 responden. Teknik pengumpulan data yang digunakan adalah 1) wawancara mendalam (depth interview) Untuk memperoleh gambaran yang lebih komprehensif mengenai sejauhmana efektifitas program penanggulangan kemiskinan, maka diperlukan wawancara mendalam kepada stakeholder yang terkait dengan program penanggulangan 
kemiskinan. 2) observasi dilakukan dengan pengamatan dan pencatatan langsung atas segala yang ada kaitannya dengan obyek penelitian, teknik ini sebagai alat untuk melengkapi teknik lainnya. 3) Dokumen dengan mencatatan peristiwa yang sudah berlalu. Dokumen bisa berbentuk tulisan, gambar atau karya-karya monumental dari seseorang. Jadi, Peneliti melakukan dokumentasi pelaksanaan kegiatan program pemberdayaan perempuan dan penelitian melalui foto, video, atau rekaman sebagai bukti fisik pelaksanaan penelitian. Analisis data yang digunakan adalah analisis deskriptif kualitatif, dengan langkah-langkah reduksi data, sajian data, dan penarikan kesimpulan (Hoover, 2015).

Mengubah skor rata-rata tiap subaspek kualitas menjadi nilai kualitatif sesuai kriteria penilaian. Penjabaran konversi nilai tiap aspek kriteria menjadi nilai kualitatif dalam tabel berikut (Rapii, 2019).

\begin{tabular}{ll}
\hline \multicolumn{1}{c}{ Rentang Skor } & \multicolumn{1}{c}{ Kategori } \\
\hline $\mathrm{X}>\mathrm{Mi}+1,5 \mathrm{SBi}$ & Sangat Efektif \\
\hline $\mathrm{Mi}+0,5 \mathrm{SBi}<\mathrm{X} \leq \mathrm{Mi}+1,5 \mathrm{SBi}$ & Efektif \\
\hline $\mathrm{Mi}-0,5 \mathrm{SBi}<\mathrm{X} \leq \mathrm{Mi}+1,5 \mathrm{SBi}$ & Cukup Efektif \\
\hline $\mathrm{Mi}-0,5 \mathrm{SBi}<\mathrm{X} \leq \mathrm{Mi}-1,5 \mathrm{SBi}$ & Kurang Efektif \\
\hline $\mathrm{X} \leq \mathrm{Mi}-1,5 \mathrm{SBi}$ & Tidak Efektif \\
\hline
\end{tabular}

\section{HASIL DAN PEMBAHASAN}

1. Analisis kondisi Demografis

a) Jumlah Penduduk

Tabel 1. Jumlah Penduduk Desa Aikmel

\begin{tabular}{llccc}
\hline \multirow{2}{*}{ No } & \multirow{2}{*}{ Nama Dusun } & \multicolumn{3}{c}{ Penduduk } \\
\cline { 3 - 5 } & Lesa Beruk & 579 & $\mathbf{P}$ & Total \\
\hline 1 & Kp. Remaja & 696 & 580 & 1159 \\
\hline 2 & 828 & 838 & 1434 \\
\hline 3 & Kp. Karya Barat & 624 & 663 & 1685 \\
\hline 4 & Kp. Karya & 909 & 951 & 1287 \\
\hline 5 & Batu Belek & 820 & 802 & 1860 \\
\hline 6 & Cepak Daya & 395 & 388 & 1622 \\
\hline 7 & Cepak Lauk & $\mathbf{4 8 5 1}$ & $\mathbf{4 9 7 9}$ & $\mathbf{9 8 3 0}$ \\
\hline & Jumlah & & &
\end{tabular}

Sumber: Profil Desa

Jumlah penduduk Desa Aikmel tahun 2019 menunjukkan jumlah populasi penduduk perempuan lebih banyak dari pada jumlah populasi penduduk laki-laki yaitu: Di Dusun Dasan Beruk penduduknya berjumlah 1159 dimana laki-laki berjumlah 579 orang sedangkan perempuan berjumlah 580 orang. Di daerah Kp. Remaja penduduknya berjumlah 1434, perempuannya berjumlah 738 dan laki-laki 696. Terlihat bahwa jumlah penduduk yang paling banyak yaitu di daerah dusun Batu Belek yang totalnya berjumlah 1860, dimana jumlah laki-laki sebanyak 909 orang dan perempuan 951 orang, dan yang paling banyak kedua yaitu Kp. Karya Barat yang berjumlahkan 1685 yaitu laki-laki berjumlah 828 orang sedangkan perempuan berjumlah 857 orang. Dari 
sekian ribu jumlah penduduk perdusun ditotalkan dalam satu desa berjumlah 9830 orang yang dihitung dari jumlah laki-laki 4851 orang dan jumlah perempuan 4979 orang.

b) Mata Pencaharian Penduduk

Tabel 2. Jumlah Penduduk Berdasarkan Umur

\begin{tabular}{lcc}
\multicolumn{1}{c}{ Jenis Pekerjaan } & Jumlah (Orang) & Peresentase (\%) \\
\hline PNS/TNI POLRI & 186 & $19,8 \%$ \\
\hline Pegawai Swasta & 244 & $26,9 \%$ \\
\hline Karyawan Swasta & 105 & $11,2 \%$ \\
\hline Wiraswasta & 599 & $64,7 \%$ \\
\hline Pedagang & 374 & $40,4 \%$ \\
\hline Tani & 280 & $29,9 \%$ \\
\hline Pekerja Lepas & 1032 & $11.03 \%$ \\
\hline Nelayan & 2 & $2,1 \%$ \\
\hline Pensiunan & 57 & $6,9 \%$ \\
\hline Lain-lain & 638 & $68,2 \%$ \\
\hline Tidak Bekerja & 5832 & $62,38 \%$ \\
\hline \multicolumn{1}{c}{ Jumlah } & $\mathbf{9 8 3 0}$ Orang & $\mathbf{1 0 0 \%}$
\end{tabular}

Sumber: Data Desa

Mata pencaharian penduduk Desa Aikmel, jumlah penduduk yang tidak bekerja berjumlah $5832(62,38 \%)$ dan sebagai pekerja lepas sebanyak 1032 orang $(11,03 \%)$, 638 orang $(68,2 \%)$ sebagai pekerja lain-lain, 186 orang (19,8\%) PNS/TNI POLRI, 244 orang $(26,9 \%)$ pegawai swasta, 105 orang $(11,2 \%)$ karyawan swasta, 599 orang $(64,7 \%)$ wiraswasta, 374 orang $(40,4 \%)$ pedagang, 280 orang $(29,9 \%)$ tani, 2 orang $(2,1 \%)$ nelayan, dan 57 orang $(6,9 \%)$ yang sebagai pensiunan. Dari total jumlah tersebut, sebagian besar penduduknya tidak bekerja dan hanya sebagai pekerja lepas. Mayoritas perempuan di desa bekerja sebagai wiraswasta dan pedagang.

c) Pendidikan

Tabel 3. Jumlah Penduduk Berdasarkan Jenis Pendidikan

\begin{tabular}{lcc}
\hline \multicolumn{1}{c}{ Pendidikan } & Jumlah (Orang) & Peresentase (\%) \\
\hline Belum Sekolah & 1421 & $18,2 \%$ \\
\hline Sekolah Dasar (SD) & 1150 & $14,7 \%$ \\
\hline SMP & 537 & $6,89 \%$ \\
\hline SMA & 500 & $6,41 \%$ \\
\hline Tidak Tamat SD & 288 & $3,69 \%$ \\
\hline Tidak Tamat SMP & 1251 & $16,5 \%$ \\
\hline Tidak Tamat SMA & 1591 & $20,4 \%$ \\
\hline Kuliah & 255 & $3,27 \%$ \\
\hline Tamat Kuliah & 797 & $10,2 \%$ \\
\hline \multicolumn{1}{c}{ Jumlah } & $\mathbf{7 7 9 0}$ & $\mathbf{1 0 0 \%}$ \\
\hline
\end{tabular}

Sumber: Data Desa

Menunjukkan bahwa tingkat pendidikan penduduk desa yang tidak tamat SD berjumlah 288 orang, tidak tamat SLTP/SMP sebanyak 1251 orang, dan yang tidak 
tamat SLTA/SMA sebanyak 1591 orang. Total jumlahnya sebanyak 3130 yang tidak tamat sekolah dari 7790 orang.

2. Program Pemberdayaan Kesejahteraan Keluarga (PKK)

a) Pelatihan Keterampilan Menjahit

Tabel 4. Jumlah Wanita Tukang Jahit Yang Sudah Berdiri

\begin{tabular}{ccccc}
\hline \multirow{2}{*}{ No } & \multirow{2}{*}{ Usia } & \multirow{2}{*}{ Jumlah } & \multicolumn{2}{c}{ Penghasilan Perbulan } \\
\cline { 3 - 5 } & & & Sebelum & Setelah \\
\hline 1 & $5-10$ Tahun & 0 & - & - \\
\hline 2 & $10-25$ Tahun & 13 & Tidak tentu & 1.300 .000 \\
\hline 3 & $25-45$ Tahun & 25 & 1.300 .000 & 3.000 .000 \\
\hline 4 & $45-60$ Tahun & 45 & 4.550 .000 & 6.050 .000 \\
\hline 5 & 60 Tahun Keatas & 7 & Tidak tentu & 850.000 \\
\hline
\end{tabular}

Sumber: Data diolah

Terlihat bahwa jumlah penghasilan perempuan yang awalnya hanya sebagai ibu rumah tangga saja yang tidak mempunyai pendapatan sendiri kini bisa menciptakan penghasilan sendiri guna memenuhi kebutuhannya sehari-hari. Peningkatan penghasilan meningkat cukup signifikan yaitu 50\% dari hasil sebelumnya.

b) Pelatihan Tata Boga

Jumlah perempuan yang telah ikut pelatihan, jenis pelatihan tata boga yang dipraktikan, yaitu pembuatan kerupuk, pembuatan tempe, dan pembuatan tahu. Dari hasil tata boga ibu PKK mampu mendirikan usahanya sendiri.

Tabel 05. Jumlah Pengusaha Kerupuk

\begin{tabular}{lllcc}
\hline \multirow{2}{*}{ No } & \multirow{2}{*}{ Usia } & Jumlah & \multicolumn{2}{c}{ Penghasilan Perbulan } \\
\cline { 3 - 5 } & & & Sebelum & Setelah \\
\hline 1 & $5-10$ Tahun & 0 & - & - \\
\hline 2 & $10-25$ Tahun & 0 & - & - \\
\hline 3 & $25-45$ Tahun & 23 & - & 2.000 .000 \\
\hline 4 & $45-60$ Tahun & 50 & - & 2.250 .000 \\
\hline 5 & 60 Tahun Keatas & 17 & - & 1.500 .000 \\
\hline
\end{tabular}

Sumber: Data diolah

Terlihat pada tabel di atas yaitu pengusaha kerupuk yang awalnya hanya sebagai ibu rumah tangga kini bias mempunyai penghasilan sendiri dalam upaya membantu suami dalam bekerja dan menambah pendapatan keluarga melalui usaha tersebut. Prosentase peningkatan pendatapan dari usaha gerupuk yaitu sebesar 55,5\%.

Tabel 6. Jumlah Pengusaha Tempe

\begin{tabular}{llccc}
\hline \multirow{2}{*}{ No } & \multirow{2}{*}{ Usia } & \multirow{2}{*}{ Jumlah } & \multicolumn{2}{c}{ Penghasilan Perbulan } \\
\cline { 3 - 5 } & & 0 & Sebelum & Setelah \\
\hline 1 & $5-10$ Tahun & 19 & - & - \\
\hline 2 & $10-25$ Tahun & 28 & - & 2.000 .000 \\
\hline 3 & $25-45$ Tahun & 43 & - & 3.000 .000 \\
\hline 4 & $45-60$ Tahun & 0 & - & - \\
\hline 5 & 60 Tahun Keatas & & & \\
\hline
\end{tabular}

Sumber : Data diolah 
Dari data tersebut terlihat bahwa berbagai jumlah pendapatan yang didapatkan oleh pengusaha tempe dalam satu bulan, penghasilan tersebut dihitung dengan jumlah modal yang dikeluarkan dan penghasilan masing-masing pengusaha tempe terbilang naik yang awalnya hanya sebagai ibu rumah tangga biasa. Peningkatan dari penghasilan usaha tempe sebesar $47,7 \%$.

Tabel 7. Jumlah Pengusaha Tahu

\begin{tabular}{ccccc}
\hline \multirow{2}{*}{ No } & \multirow{2}{*}{ Usia } & \multirow{2}{*}{ Jumlah } & \multicolumn{2}{c}{ Penghasilan Perbulan } \\
\cline { 4 - 5 } & & & Sebelum & Setelah \\
\hline 1 & $5-10$ Tahun & 9 & - & 1.500 .000 \\
\hline 2 & $10-25$ Tahun & 17 & - & 1.600 .000 \\
\hline 3 & $25-45$ Tahun & 26 & - & 2.100 .000 \\
\hline 4 & $45-60$ Tahun & 38 & - & 3.000 .000 \\
\hline 5 & 60 Tahun Keatas & 0 & - & - \\
\hline Sumber: Data diolah & &
\end{tabular}

Dari data tersebut menunjukkan adanya peningkatan penghasilan sebelumnya tidak ada dan hanya sebagai rumah tangga, kini mampu mendirikan usahanya sendiri dan menghasilkan pendapatan sendiri guna memenuhi kebutuhan keluarga. Peningktan dari hasil latiha tata boga pengusaha tahau sebesar $42,2 \%$.

3. Instrumen Analisis Program Pemberdayaan Kesejahteraan Keluarga (PKK) dalam Menanggulangi Kemiskinan

Menjadi tolok ukur efektivitas program pemberdayaan perempuan dalam menanggulangi kemiskinan yaitu besarnya perubahan kondisi perempuan desa setelah mengikuti pelatihan program dan dihubungkan dengan besarnya persentase informan yang menyatakan keterkaitan program dengan tingkat penghasilan. Untuk memudahkan pemahaman dilakukan pengelompokan nilai rata-rata tingkat kondisi masyarakat sebagai berikut:

Tabel 8. Tingkat Efektivitas Program Pemberdayaan Perempuan

\begin{tabular}{clcl}
\hline & \multicolumn{1}{c}{ Indikator } & Persentase & Kategori \\
\cline { 2 - 4 } Program & Partisipasi & $78,12 \%$ & Sangat efekti \\
\cline { 2 - 4 } pemberdayaa & Sikap kerja sama & $46,87 \%$ & Tidak efektif \\
\cline { 2 - 4 } $\begin{array}{c}\text { n perempuan } \\
\text { PKK }\end{array}$ & Pengetahuan & $62,50 \%$ & Cukup efektif \\
\cline { 2 - 4 } & Keterampilan & $85,93 \%$ & Sanga tefekti \\
\cline { 2 - 4 } & Mengembangkan & $54,68 \%$ & Kurang efektif \\
\cline { 2 - 4 } & Pengetahuan & & \\
\cline { 2 - 4 } & Inovasi & $65,62 \%$ & Cukup efektif \\
\cline { 2 - 4 } & Informasi & $23,43 \%$ & Sangat efekti \\
\cline { 2 - 4 } & Usaha diri & $89,60 \%$ & Cukup efektif \\
\hline
\end{tabular}

Sumber : Data diolah

Tingkat partisipasi perempuan dalam kegiatan pelatihan yang dijalankan oleh program terbilang sangat efektif yaitu sebanyak $(78,12 \%)$ yang ikut berpartisi pasiaktif dalam kegiatan tersebut. Sikap kerja sama masih dibilang tidak efektif berkisar 
$(46,87 \%)$ yang mementingkan kepentingan umum sedangkan (53\%) lebih memilih mementingkan diri sendiri. Untuk pengetahuan baik itu pengetahuan dasar maupun pengembangan pengetahuan sudah terbilang cukup efektif dari sebelumnya yaitu berkisar $(62,50 \%)$. Tingkat keterampilan perempuan dalam menciptakan produksaat pelatihan yaitu $(85,93 \%)$ sudah terbilang sangat efektif. Dalam mengembangkan pengetahuan masih terbilang kurang efektif yaitu hanya $(54,68 \%)$ dimana para perempuan ataupun anggota program masih dalam pelatihan-pelatihan dasar.Untuk tingkat inovasi terbilang cukup efektif yaitu $(65,62 \%)$ dilihat dari jenis produkyang dihasilkan dalam pelatihan. Mengenai informasi terbilang tidak efektif (23,4\%)dan untuk usaha mandiri sudah sangat efektif sekali yaitu $(89,60 \%)$ dilihat daribanyaknya perempuan yang telah mendirikan usahanya dari hasil kegiatan pelatihan program, ini juga memengaruhi tingkat penghasilan perempuan, jadi persentase jumlah perempuan yang mengalami peningkatan penghasilan dari program yaitu sebanyak $(71,87 \%)$ terbilang cukup efektif.

Program PKK pada dasarnya merupakan suatu program pembangunan yang berorientasi untuk menanggulangi kemiskinan dengan menitikberatkan pada pemberdayaan masyarakat sebagai pendekatan operasionalnya. Untuk itu dalam implementasi program PKK masyarakat khususnya perempuan diberikan tanggung jawab dan kesempatan yang luas untuk menjadi subyek utama dari program yang dilaksanakan. Dengan demikian program PKK merupakan wahana bagi partisipasi aktif masyarakat dalam pelaksanaan pembangunan sekaligus sebagai ajang pengembangan kapasitas masyarakat yang memberikan kesempatan besar bagi terwujudnya pemberdayaan masyarakat.

Dampak dari program PKK terhadap rumah tangga peserta program PKK secara kualitatif berdampak kepada kehidupan yang semakin baik. Hal ini karena sebanyak 90 rumah tangga peserta program PKK dari sebelumnya tidak punya usaha kini mereka punya usaha. Pembahasan hasil penelitian menunjukkan bahwa pelaksanaan program PKK telah memberikan manfaat yang positif terhadap pengentasan kemiskinan di Kecamatan Aikmel yang menjadi lokasi penelitian ini. Hal tersebut didukung kegiatan non fisik berupa kegiatan ekonomi produktif yang utamanya dijalankan oleh kaum perempuan. Kesemuanya itu memberikan kesempatan dan keberdayaan bagi masyarakat luas, khususnya masyarakat miskin sebagai kelompok sasaran, untuk secara berangsur angsur melepaskan diri dari belenggu kemiskinan, dengan prakarsa sendiri. Implementasi program PKK di lokasi penelitian dapat menjadi cermin bahwa kebijakan tersebut secara konseptual sangat sesuai dengan harapan maupun aspirasi dari masyarakat miskin. Oleh karena itu mereka memberikan dukungan yang besar terhadap implementasi program.

\section{SIMPULAN}

Berdasarkan penelitian yang dilakukan didapatkan temuan bahwa masih terdapat banyak perempuan miskin di Kecamatan Aikmel yang membutuhkan penanganan khusus dalam rangka pengentasan kemiskinan yang dialami. Dilihat dari profil perempuan miskin di Kecamatan Aikmel, diketahui bahwa mereka masih tinggal di rumah yang tidak layak huni, memiliki akses pendidikan yang terbatas serta pendapatan 
yang rendah. Kondisi demikian menjadikan mereka terbelenggu dalam lingkaran kemiskinan. Pengentasan kemiskinan desa melalui pemberdayaan perempuan ini dapat membawa perubahan kelompok perempuan menjadi termotivasi untuk berkembang untuk mendapatkan penghasilan melalui program kesejahteraan keluarga, kelompok sasaran merasa lebih kuat dan bersemangat, karena masyarakat desa merasa bersaudara, senang bergotong royong. Metode partisipasi perempuan yang diterapkan mampu merangsang kelompok sasaran untuk aktif mengambil keputusan dan berani mencari akar masalah yang dihadapi, serta mampu menggali potensinya, sehingga mampu mencari solusi dari permasalahanya. Pemberdayaan perempuan dengan pendekatan ekonomi merupakan realitas sosial yang sangat diharapkan masyarakat miskin. Pemberian praktik keterampilan yang menyesuaikan potensi lokal dapat mengembangkan usaha bersama ekonomi produktif kelompok perempuan, yang dapat meningkatakan penghasilan keluraga. Pendekatan lingkungan dapat meningkatkan pemahaman pentingnya memelihara lingkungan akan menunjang kelestarian lingkungan untuk genersai yang akan datang. Hasil penelitian sebagai berikut, yaitu indikator keberhasilan pelatihan diantaranya adalah bertambahnya pengetahuan dan keterampilan warga, serta diperolehnya pendapatan hasil usaha yang meningkat. Keberlanjutan program pemberdayaan perempuan ditunjukkan dengan telah adanya pengembangan produk atau variasi produk dan terbentuknya kemandirian.

\section{DAFTARPUSTAKA}

BNP2TKI. (2019). Laporan Kinerja Kementerian Pemberdayaan Perempuan dan Perlindunga Anak. In Program. https://doi.org/10.3406/arch.1977.1322

Diwanti, D. P., Andriyani, E., \& Herawati, R. S. (2019). Pemberdayaan Perempuan Melalui Bina Usaha Ekonomi Keluarga 'Aisyiyah (BUEKA). NUSANTARA: $\begin{array}{llll}\text { Jurnal Ilmu Pengetahuan } & \text { Sosial, }\end{array}$ https://doi.org/10.31604/jips.v6i2.2019.194-207

Goyena, R., \& Fallis, A. . (2019). Model Pemberdayaan Perempuan Miskin Melalui Pelatihan Kewirausahaan Berbasis Potensi Lokal Di Kecamatan Wedi Kabupaten Klaten. Journal of Chemical Information and Modeling, 53(9), 1689-1699. https://doi.org/10.1017/CBO9781107415324.004

Hoover, K. D. (2015). The Methodology Of Empirical Macroeconomics (Vol. 3, Issue 2). http://repositorio.unan.edu.ni/2986/1/5624.pdf

KPPPA. (2019). Profil Anak Indonesia Tahun 2019. In Profil Anak Indonesia. https://www.kemenpppa.go.id/lib/uploads/list/15242-profil-anak-indonesia_2019.pdf

Kuncoro, A., \& Kadar, K. (2016). Pengaruh Pemberdayaan Perempuan dan Peningkatan Sumberdaya Ekonomi Keluarga. BUANA GENDER: Jurnal Studi Gender Dan Anak, 1(1), 45. https://doi.org/10.22515/bg.v1i1.67

Rapii, M. (2019). Mengukur Potensi Wirausaha pada Program Pelatihan. JMK (Jurnal Manajemen Dan Kewirausahaan), 4(2), 126-135. https://doi.org/http://dx.doi.org/10.32503/jmk.v4i2.487

Saptatiningsih, R. I. (2015). Seminar nasional universitas pgri yogyakarta 2015. Proceeding Seminr Nasional Universitas PGRI Yogyakarta, 1-11, 412-418.

Sukidjo, Teguh Sihono, \& M. (2014). Pemberdayaan Kelompok Perempuan Dalam Pengentasan Kemiskinan Berbasis Pengembangan Usaha Mikro. Jurnal Economia, 10(1), 1-10. https://doi.org/10.21831/economia.v10i1.4171 